\title{
6.2 Теоретичні аспекти та методики оцінки фінансового стану підприємства в системі фінансово-економічної безпеки
}

В умовах трансформаційних перетворень економіки держави фінансовоекономічна безпека є складовою економічної безпеки і вважається головною, оскільки за ринкових умов господарювання фінанси $є$ «локомотивом» будь-якої економічної системи.

Фінансово-економічна безпека - це такий фінансовий стан, що характеризується, по-перше, збалансованістю та якістю сукупності фінансових інструментів, технологій та послуг, які використовуються підприємством, подруге, стійкістю до зовнішніх та внутрішніх загроз, по-третє, здатністю фінансової системи підприємства забезпечити реалізацію його фінансових інтересів, цілей та задач достатніми обсягами фінансових ресурсів.

На сьогодні питання якісного стратегічного управління системою фінансово-економічної безпеки є необхідним для самостійного розроблення фінансово-економічної стратегії підприємства відповідно до цілей загальноекономічної державної стратегії, а також для забезпечення фінансової рівноваги, стійкості, платоспроможності і ліквідності підприємства в довгостроковому періоді в умовах невизначеного і конкурентного середовища.

Метою наукового дослідження $\epsilon$ необхідність розроблення та вдосконалення теоретичних та методологічних аспектів поняття фінансового стану підприємства та визначення основних методик його оцінки в системі фінансово-економічної безпеки.

Для досягнення поставленої мети необхідно вирішити такі завдання:

- визначити суть і значення фінансової стійкості підприємства в системі управління фінансово-економічною безпекою;

- провести оцінку фінансово-економічної безпеки діяльності підприємства на основі певних економічних показників;

- проаналізувати основні індикатори фінансово-економічної безпеки; 
- запропонувати основні напрями вдосконалення управління системою забезпечення фінансово-економічної безпеки на підприємстві.

Методичну базу даного дослідження складають: монографічний метод дослідження інформаційних, літературних джерел і наукових праць з проблем вдосконалення фінансово-економічного стану підприємства.

Теоретичною та методологічною базою дослідження слугували економічні теорії сучасних авторів щодо розвитку та удосконалення використання фінансових ресурсів підприємства, комплексного аналізу та оцінки показників фінансової стійкості в системі фінансово-економічної безпеки, публікації вітчизняних і зарубіжних вчених з тематики дослідження, методики аналізу фінансового стану підприємства та висновки автора.

Однією з характеристик стабільного фінансового стану підприємства $є$ його фінансова стійкість. Фінансова стійкість підприємства є однією з головних умов життєдіяльності, розвитку й забезпечення високого рівня конкурентоспроможності підприємства. Саме фінансова стійкість підприємства характеризує ефективність операційного, фінансового та інвестиційного розвитку, містить необхідну інформацію для інвесторів, а також відображає здатність підприємства відповідати за своїми боргами і зобов’язаннями.

У вітчизняній та закордонній практиці немає єдиного трактування поняття «фінансова стійкість підприємства». Варто зазначити, що більшість наукових поглядів спирається на ототожнення або споріднення понять «фінансовий стан», «фінансова стабільність» та «фінансова стійкість».

На нашу думку, необхідно детально розглянути визначення кожного 3 наведених показників. І.О. Бланк пропонує визначити фінансовий стан підприємства як рівень збалансованості окремих елементів активів і пасивів підприємства, а також рівень ефективності їх використання [364, с. 321].

На наш погляд, такі показники, як ділова активність та надійність, мають доповнювати інші показники діяльності підприємства, бо самостійно не дають можливості оцінити ефективність функціонування організації. 
Г.Б. Пічугіна стверджує, що під фінансовим станом підприємства можна розуміти кінцеві результати його діяльності, що, на нашу думку,є недоцільним, адже не можна ототожнювати всі аспекти діяльності підприємства тільки 3 прибутком або збитком [365, с. 277]. Л.О. Коваленко, враховуючи більшість рис підприємства як господарюючого суб'єкта ринкових відносин, пропонує визначати фінансовий стан як характеристику його фінансової конкурентоспроможності, ефективність використання фінансових ресурсів і капіталу, виконання зобов'язань перед державою та іншими суб'єктами господарювання [366, с. 411]. О.О. Терещенко зазначає, що фінансова рівновага передбачає, що грошові надходження підприємства дорівнюють або перевищують потребу в капіталі для виконання поточних платіжних зобов'язань [367, c. 277].

На думку М.Д. Білик, О.В. Павловської, Н.М. Притуляк та Н.Ю. Невмержицької, фінансова рівновага визначається як відповідність обсягів формування та споживання власних фінансових ресурсів [368, с. 117-128]. С.3. Мошенський та О.В. Олійник [369, с. 82], розглядаючи сутність фінансової стійкості, визначають основною передумовою іiї дотримання умов фінансової рівноваги між власними та запозиченими джерелами.

У своїх наукових працях О.С. Філімоненко [370, с. 304], Ю.С. Цал-Цалко [371, с. 315], Н.Н. Селезньова та А.Ф. Іонова розглядають фінансову стабільність підприємства через аспект поняття платоспроможності, тобто фінансова стабільність підприємства $є$ таким станом його активів та пасивів, який $\epsilon$ достатнім для погашення усіх зобов'язань. К. Друрі пропонує оцінювати фінансову стабільність підприємства через його фінансову незалежність, що пов'язана із загальною структурою підприємства, ступенем залежності від зовнішніх джерел фінансування.

Досить цікавим, на нашу думку, є підхід до визначення фінансової стабільності підприємства представників американської школи менеджменту Дж.Ф. Маршалла та В.К. Бансала. Вони розглядають фінансові інновації та тенденції, що виступають зовнішнім чинниками стабільності підприємства. На 
їхню думку, прогнозування очікуваних значень фінансових показників i допустимих діапазонів їх похибки має орієнтуватися на фінансові продукти.

Аналіз досвіду вітчизняних та зарубіжних учених дає змогу виокремити чотири основних напрями визначення фінансової стійкості:

1) як стан підприємства або ресурсів. Н.В Алєксеєнко стверджує, що фінансова стійкість підприємства - це стан його матеріальних, економічних i трудових ресурсів їх розподіл використання, які забезпечують розвиток підприємства на основі зростання прибутку i капіталу за збереження платоспроможності та кредитоспроможності в умовах допустимого рівня ризиків [372, с. 56-60]. О.М. Зайцев розглядає фінансову стійкість підприємства як стан підприємства, за якого зберігається здатність ефективного функціонування і стабільного прогресивного розвитку за негативних впливів зовнішнього середовища. В.А.Медведєв розглядає фінансову стійкість як рівний збалансований стан економічних ресурсів, який забезпечує стабільну прибутковість і нормальні умови для розширеного відтворення в тривалій перспективі з урахуванням важливих чинників;

2) як рівновага або здатність повертатись до неї. С.Н. Анохін розглядає фінансову стійкість як такий рівноважний стан промислового підприємства, за якого економічні й управлінські рішення здатні регулювати основні фактори стійкого положення підприємства: управління, виробництва, фінансів, персоналу і стратегії в заданих межах ризику [373, с. 30]. На думку О.М. Колодізєва фінансова стійкість - це стан рівноваги або здатність повертатися у цей стан відкритої соціально-економічної системи (підприємство).

3) як здатність підприємства (системи). В.3. Бугай стверджує, що фінансовою стійкістю є здатність підприємства поглинати зовнішні й внутрішні дестабілізуючі фактори через ефективне застосування своїх ресурсів за рахунок використання й удосконалення економічного потенціалу [374, с.34]. А.В. Василенко пропонує розглянути фінансову стійкість як здатність системи зберігати свій працездатний стан щодо досягнення запланованих результатів за наявності різних мінливих впливів [375, с. 39]. В.Л. Іванов розкриває фінансову 
стійкість як здатність економічної системи не відхилятися від свого стану (статистичного або динамічного) за різних внутрішніх i зовнішніх дестабілізуючих впливів за рахунок ефективного формування і використання фінансових, виробничих організаційних механізмів [376, с. 32-39];

4) як комплекс складників. О.В. Ареф'єва, Д.М. Городянська розглядають фінансову стійкість як сукупність взаємозумовлених та взаємопов'язаних складників, які за будь-яких умов забезпечують здатність до ведення діяльності підприємств, запас ресурсів (ресурсного потенціалу) та збалансований процес функціонування.

На думку О.Є. Журавльової, сутність фінансової стійкості проявляється у оптимальній структурі капіталу, що забезпечується домінуючою часткою власного капіталу в загальному обсязі авансованого в підприємство капіталу, що дає змогу підтримувати фінансову незалежність від зовнішніх кредиторів та забезпечити безперервний виробничо-господарський процес [377, с.523].

I.Г. Ловінська зазначає, що фінансова стійкість являє собою певний стан рахунків підприємства, що гарантує його постійну платоспроможність [378, с. 252]. Варто зазначити, що, на нашу думку, таке визначення фінансової стійкості не може певною мірою задовольнити потребу в оцінці ефективності діяльності підприємства. О.А. Островська визначає фінансову стійкість підприємства як здатність підприємства функціонувати та розвиватися, зберігати рівновагу своїх активів та пасивів у мінливому внутрішньому та зовнішньому середовищі, яка гарантує його постійну платоспроможність та інвестиційну привабливість у межах допустимого рівня ризику [379, с. 182].

На думку А.Д. Шеремета, стійкість та стабільність фінансового стану залежить від результатів операційної та фінансово-інвестиційної діяльності підприємства, а стійкий фінансовий стан, своєю чергою, здійснює позитивний вплив на діяльність організацій. Н.А. Мамонтова характеризує фінансову стійкість як такий стан підприємства, за якого забезпечуються стабільна фінансова діяльність, постійне перевищення доходів над витратами, вільний обіг 
грошових коштів, ефективне управління фінансовими ресурсами, безперервний процес виробництва і реалізації продукції [380, с. 105].

Колектив авторів на чолі з А.М. Поддєрьогіним визначає фінансову стійкість підприємства як такий його стан, що дає змогу за рахунок власних і позикових коштів забезпечити поточну виробничу діяльність та інвестиційноінноваційний розвиток підприємства, зберігаючи темпи приросту власного капіталу, платоспроможність та кредитоспроможність [381, с. 14].

На нашу думку, варто розглядати фінансову стійкість як комплексне поняття, в якому відображається стабільний фінансовий стан підприємства, за якого ефективно формуються, розподіляються та використовуються фінансові ресурси, забезпечуються фінансова автономія, платоспроможність, дохідність та рентабельність, розвиток діяльності на поточний та майбутній періоди.

Враховуючи вищезазначені трактування, можна зазначити, що фінансово стійким є підприємство, яке характеризується такими ознаками: високою платоспроможністю (здатністю відповідати за своїми зобов'язаннями); високою кредитоспроможністю (здатністю платити за кредитами, виплачувати відсотки по них і погашати їх точно в строк); високою рентабельністю (прибутковістю, що дозволяє фірмі нормально і стійко розвиватися, вирішуючи при цьому проблему взаємини акціонерів i менеджерів за рахунок підтримки на достатньому рівні дивідендів і курсу акцій підприємства); високою ліквідністю балансу (здатністю покривати свої пасиви активами відповідної і перевищує терміновості перетворення їх на гроші).

Дослідивши точки зору різних авторів можна помітити, що єдиного визначення щодо поняття фінансової стійкості не існує, з цього випливає що фінансова стійкість - поняття широке.

1. Фінансова стійкість визначає фінансову безпеку підприємства, а також його фінансову незалежність від інвесторів та кредиторів.

2. Фінансова стійкість підприємства - це здатність фінансової системи зберігати рух грошових коштів, незважаючи на зовнішні та внутрішні фактори, які на неї впливають. 
3. Фінансова стійкість формується в процесі операційної, фінансової та інвестиційної діяльності підприємства, є результатом взаємодії всіх елементів системи фінансових відносин підприємства, а отже є головним компонентом загальної економічної стійкості підприємства.

4. Фінансова стійкість підприємства - це здатність здійснювати господарську діяльності в умовах підприємницького ризику i мінливого середовища бізнесу з метою зміцнення конкурентних переваг з урахуванням інтересів суспільства і держави та максимізації добробуту власників.

5. Фінансова стійкість підприємства в довгостроковому плані характеризується співвідношенням його позикових та власних коштів. Сутність фінансової стійкості визначається ефективним формуванням, розподілом i використанням фінансових ресурсів.

Аналіз трактування поняття «фінансова стійкість» підприємства дає зрозуміти, що дане визначення розглядається, як у вузькому, так і в широкому визначенні. Доцільним було б надати, власне визначення такого поняття, як «фінансова стійкість» підприємства.

Отже, фінансова стійкість - це більш узагальнена характеристика фінансового стану підприємства, тобто здатність суб'єкта господарювання розвиватися та функціонувати, забезпечувати фінансову незалежність та зберігати рівновагу своїх пасивів та активів, що гарантує інвестиційну привабливість та платоспроможність підприємства.

Процес управління та регулювання фінансової стійкості підприємства включає визначення методики оцінки та аналізу показників фінансового стану підприємства, а також факторів, що впливають на зміну даних показників в умовах ринкової економіки.

Першочерговим завданням проведення оцінки фінансового стану є чітке окреслення мети та завдань його здійснення. Слід відзначити, що найчастіше внутрішніми службами підприємства оцінка фінансового стану здійснюється 3 метою впровадження певних заходів щодо його зміцнення та виявлення основних напрямів подальшого розвитку підприємства. 3 іншого боку постійним 
завданням у рамках функціонування системи раннього попередження i реагування в процесі здійснення фінансово-господарської діяльності $\epsilon$ діагностика банкрутства підприємства, що дозволяє вчасно запобігти небажаним наслідкам.

Зовнішня оцінка фінансового стану може проводитися акціонерами, кредиторами, інвесторами, податковими органами, підприємствами-партнерами тощо. Однак, найчастіше вона зводиться до оцінки кредитоспроможності, оскільки в сучасних умовах зростає потреба підприємств у позиковому капіталі.

До основних завдань, які комплексно розв’язуються у процесі оцінки фінансової стійкості підприємства, відносяться наступні два завдання:

а) встановлення позиції підприємства за розробленими фінансовими показниками, що зводиться до виявлення забезпеченості підприємства оборотними засобами, правильності утворення запасів товарно-матеріальних цінностей, встановлення оптимального рівня заборгованості, виявлення економічних і фінансових результатів. Правильна оцінка позиції підприємства за фінансовими показниками може бути здійснена на основі їхнього системного i взаємозалежного аналізу;

б) виявлення шляхів і можливостей подальшого поліпшення фінансової діяльності, тобто встановлення в процесі оцінки відхилень показників фінансової стійкості підприємства від критичних значень. Виявлення причин цих відхилень і розробка відповідних рекомендацій сприяють поліпшенню всієї виробничої діяльності підприємства.

Метою оцінки фінансового стану підприємства $\epsilon$ пошук резервів підвищення рентабельності виробництва і зміцнення комерційного розрахунку як основи стабільної роботи підприємства і виконання ним зобов'язань перед бюджетом, банком та іншими установами.

На сьогоднішній день використовують різноманітні підходи до оцінки фінансово-економічної діяльності підприємства. Діагностування фінансового стану та забезпеченості фінансовими ресурсами діяльності підприємства доцільно проводити в наступних формах . 
- оцінка діяльності підприємства, що передбачає аналіз системи взаємопов’язаних показників, які характеризують ефективність діяльності 3 точки зору їі відповідності стратегічним цілям [382];

- експрес-діагностика стану фінансового забезпечення діяльності підприємства, яка передбачає побудову та аналіз системи взаємопов'язаних показників, що характеризують загальний фінансовий стан та структуру забезпеченості фінансовими ресурсами діяльності підприємства;

- моніторинг фінансових показників, що передбачає поточну аналітичну діяльність та контроль обмеженої кількості показників, які характеризують результати фінансової діяльності з метою визначення негативних тенденцій в їх зміні та пошуку шляхів їх вирішення;

- рейтингова комплексна оцінка стану підприємства.

В економічній літературі існують безліч науково-методичних підходів щодо оцінки фінансового стану. Традиційно у наукових джерелах виділяють методи, які у загальних рисах можна розподілити на [383, с. 55]: методи, засновані на аналізі балансу підприємства (горизонтальний, вертикальний, трендовий аналіз, метод фінансових коефіцієнтів); евристичні методи, що засновані на неформальних, інтуїтивних підходах та узагальненні досвіду розв'язання аналогічних завдань та методи експертних оцінок; економікоматематичні методи.

Також виділимо основні прийоми оцінки та аналізу фінансового стану: горизонтальний (часовий) аналіз - порівняння кожної позиції звітності 3 попереднім періодом; вертикальний (структурний) аналіз - визначення структури фінансових показників з оцінкою впливу різних факторів на кінцевий результат; трендовий аналіз - порівняння кожної позиції звітності з рядом попередніх періодів та визначення тренду, тобто основної тенденції динаміки показників, очищеної від впливу індивідуальних особливостей окремих періодів (за допомогою тренду здійснюється екстраполяція найважливіших фінансових показників на перспективний період, тобто перспективний прогнозний аналіз фінансового стану); аналіз відносних показників (коефіцієнтів) - розрахунок 
відношень між окремими позиціями звіту або позиціями різних форм звітності, визначення взаємозв'язків показників; порівняльний аналіз внутрішньогосподарський аналіз зведених показників звітності за окремими показниками самого підприємства та його дочірніх підприємств (філій); факторний аналіз - визначення впливу окремих факторів (причин) на результативний показник детермінованих (розділених у часі) або стохастичних (що не мають певного порядку) прийомів дослідження. При цьому факторний аналіз може бути як прямим, коли результативний показник розділяють на окремі складові, так і зворотним (синтез), коли його окремі елементи з'єднують у загальний результативний показник.

Для проведення оцінки фінансової стійкості необхідно виділити основні фактори, що впливають на фінансово-економічну діяльність підприємства. Для управління окремими із цих факторів, посилення чи послаблення впливу на фінансову стійкість підприємства їх можна об’єднати в групи, таблиця 1.1.

Таблиця 1.1

Класифікація факторів, що впливають на фінансову стійкість підприємства

\begin{tabular}{|l|l|}
\hline \multicolumn{1}{|c|}{ Прізвище автора } & \multicolumn{1}{|c|}{ Групи факторів (чинників) } \\
\hline М.Д. Білик, О.В. Павловська, & - чинники першого рівня (базові) \\
Н.М. Притуляк, Н.Ю. Невмержицька & - чинники другого рівня (похідні): \\
& зовнішні, внутрішні; \\
& - чинники третього рівня (деталізуючі) \\
\hline I.О. Бланк & чинники, що пов'язані з операційною \\
& діяльністю; \\
& - чинники, що пов'язані з інвестиційною \\
& діяльністю; \\
& - чинники, що пов'язані з фінансовою \\
& діяльністю \\
\hline В.І. Оспіщев, І.В. Нагорна & -економічні; \\
& - соціально-політичні; \\
& - фінансові; \\
& - демографічні; \\
& - науково-технічний прогрес \\
\hline В.В. Хачатрян, Л.С. Усова & - зовнішні (міжнародні, національні, \\
& ринкові); \\
& - внутрішні (якісні; кількісні) \\
\hline
\end{tabular}


Продовження табл. 1.1

\begin{tabular}{|l|l|}
\hline С.В. Мних, Н.С. Барабаш & - за місцем виникнення; \\
& - за масштабом впливу; \\
& - за структурою; \\
& - за можливістю прогнозування; \\
& -за важливістю результату; \\
& - за ступенем впливу на діяльність \\
& підприємства; \\
& - за часом; \\
& - за ймовірністю реалізації \\
\hline
\end{tabular}

Чинники І рівня - це узагальнюючі (базові) чинники, які є результатом впливу чинників II і III рівнів і водночас виступають генератором взаємодії більш дрібних чинників [384, с. 194]. До чинників I рівня відносять: а) фазу економічного розвитку системи; б) стадію життєвого циклу підприємства. Фаза економічного розвитку системи впливає на темпи реалізації продукції, виробництва, рівень інвестицій підприємства у товарні запаси, доходи підприємства та населення. Так, у період економічної кризи темпи реалізації продукції відстають від темпів її виробництва, зменшуються інвестиції в товарні запаси, що, в свою чергу, призводить до ще більшого скорочення збуту за одночасного зменшення доходів підприємстві рівня доходів населення. Таким чином, знижується ліквідність підприємств та їх платоспроможність, що негативно відбивається на рівні фінансової стійкості підприємства [385, с. 171]. Наступним базовим чинником I рівня виступає стадія життєвого циклу підприємства. Даний чинник є основоположним при визначенні загальноекономічної мети діяльності підприємства, для досягнення якої будуть спрямовані всі інші його стратегії. На рівні підприємства необхідно значну увагу приділяти з'ясуванню специфіки кожної окремої стадії його розвитку, оскільки специфіка кожної окремої стадії розвитку підприємства буде визначати також потенційні його можливості щодо забезпечення обсягів діяльності, а отже, величини прибутку, формування приросту активів та їх фінансування за рахунок окремих видів джерел, зокрема власними фінансовими ресурсами у необхідному обсязі з метою самофінансування, і разом з цим опосередковано формуватиме 
певний ступінь фінансової стійкості та стабільності фінансової діяльності підприємства.

Чинники II рівня - похідні, адже вони є результатом дії базових чинників. До складу похідних чинників належать наступні: середній рівень доходів населення; демографічна ситуація; соціальна політика держави; податкова політика держави; грошово-кредитна політика; амортизаційна політика; загальний рівень стабільності; стратегія управління обсягами діяльності; стратегія управління активами; стратегія управління капіталом; стратегія управління грошовими потоками. Чинники II рівня бувають зовнішніми i внутрішніми. Зовнішніми чинниками II рівня $є$ ті. вплив яких пов'язаний 3 характером державного регулювання (податкова, грошово-кредитна, амортизаційна, соціальна, демографічна політика тощо). До внутрішніх похідних факторів другого рівня, що забезпечують фінансову стійкість, належать стратегія управління обсягами діяльності підприємства, політика управління його активами, власним і позиковим капіталом. Розроблена стратегія передбачає загальну потребу в активах, їх оптимальну структуру при одночасному визначенні джерел фінансування цієї потреби та оптимізації структури капіталу, що, в свою чергу, є гарантом досягнення ефективної пропорційності між коефіцієнтом фінансової прибутковості та коефіцієнтом фінансової стійкості підприємства. Досягнення пропорційності між коефіцієнтом прибутковості та коефіцієнтом фінансової стійкості має бути основною метою підприємства, оскільки це один із чинників, що сприяє максимізації його ринкової вартості [382, с. 100].

Чинники III рівня є деталізуючими. 3 їх допомогою з’ясовують і деталізують механізм впливу похідних чинників на фінансовий стан підприємства. Деталізуючими чинниками $\epsilon$ : середній рівень доходів населення; рівень конкуренції; рівень інфляції; склад та структуру активів; стратегію управління власними фінансовими ресурсами та позиковим капіталом; стратегію управління ризиком. Вплив чинників III рівня на фінансову стійкість підприємства $є$ диференційованим. Тому за їх значущістю одним із найважливіших внутрішніх чинників фінансової стійкості $є$ оптимізація складу та структури активів 
підприємства. Аналогічний вплив має також вірний вибір стратегії управління активами. Значною мірою фінансова стійкість підприємства залежить від якості політики управління поточними активами, від того, який загальний обсяг оборотних коштів має підприємство, який розмір запасів та активів у грошовій формі. При зменшенні виробничих запасів та зростанні ліквідних активів підприємство може отримувати більший обсяг прибутку за рахунок залучення в оборот додаткових коштів, однак разом 3 цим виникає ризик виникнення неплатоспроможності підприємства. Другий за значущістю внутрішній чинник III рівня - стратегія управління капіталом (оптимізація складу та структури джерел фінансування активів, власних фінансових ресурсів, а також правильний вибір політики управління ними). Із збільшенням обсягу власних фінансових ресурсів за рахунок внутрішніх джерел збільшуються також потенційні можливості підприємства. Важливим є як загальний розмір прибутку, так і структура його розподілу, а особливо та частка, що спрямовується на реінвестиційні цілі. Таким чином, політика розподілу та використання прибутку $є$ одним із основних внутрішніх деталізуючих чинників, що впливають на фінансову стійкість підприємства.

Зважаючи на загальне охоплення і глибину аналізу фінансового стану слід виділити експрес - аналіз та комплексний аналіз. Останні роки багато науковців і практиків підкреслюють важливість здійснення саме експрес-аналізу, який дозволяє на основі обмеженої кількості розрахунків надати об'єктивну оцінку досліджуваного напряму, яка дозволить прийняти обгрунтовані управлінські рішення. Основною відмінністю між експрес-аналізом і комплексним аналізом фінансового стану є ступінь деталізації аналітичних розрахунків. В той же час комплексний аналіз дозволяє всебічно оцінити фінансовий стан підприємства на основі одночасного та узгоджуваного вивчення сукупності різних параметрів, що всебічно характеризують фінансово-господарську діяльність [386, с. 108].

Залежно від спектра досліджуваних питань аналіз фінансової стійкості підприємств можна розділити на два види: 
- повний, коли вивчаються всі аспекти діяльності підприємства, тобто зовнішні і внутрішні його зв'язки;

- тематичний, коли розглядається тільки вузьке коло питань, що дає змогу виявити можливості поліпшення окремих напрямів діяльності підприємства.

У процесі аналізу фінансової стійкості слід використовувати таку методику, яка найбільшою мірою сприятиме його ефективності. Методика проведення будьякого аналізу може включати способи, правила і заходи щодо найбільш доцільного виконання роботи. В аналізі фінансової стійкості методика являє собою сукупність аналітичних способів і правил дослідження діяльності підприємства, спрямованих на вивчення різних об'єктів аналізу, які допомагають одержати найбільш повну оцінку фінансової стійкості і прибутковості підприємства.

Основними джерелами інформації для аналізу фінансової стійкості і фінансового стану в цілому є фінансова звітність, яка являє собою сукупність форм звітності, складених на основі даних фінансового обліку з метою представлення користувачам узагальненої інформації про фінансове становище і діяльність підприємства для прийняття ними визначених ділових рішень.

Для характеристики фінансової стійкості підприємства найчастіше використовується аналіз абсолютних та аналіз відносних показників.

Аналіз абсолютних показників проводиться за методикою Шеремета А.Д. та Сайфулина Р.С. Згідно 3 нею знаходиться трикомпонентний тип фінансової стійкості підприємства. Дана модель побудована на аналізі покриття власним капіталом, довгостроковим капіталом та загальним об’ємом капіталу підприємства вартості запасів та витрат [387, с. 35-39].

1. Абсолютна фінансова стійкість, коли власні джерела формування оборотних активів покривають запаси і витрати. Це означає, що підприємство не залежить від кредиторів. Дана ситуація є доволі рідкою, оскільки для підвищення рентабельності власного капіталу підприємства використовують позикові кошти для фінансування розширення діяльності підприємства та його поточної діяльності [388, c. 188]. 
2. Нормальна фінансова стійкість зустрічається у більшості існуючих успішних підприємств, адже припускає фінансування запасів та витрат за рахунок не лише власного капіталу, але й довгострокових зобов'язань, тобто довгострокового капіталу підприємства [389, С. 455-463].

3. Нестійкий фінансовий стан характеризується ситуацією, коли запаси i витрати покриваються сумою власних джерел формування оборотних активів, довгострокових позикових джерел, короткострокових кредитів і позик.

4. Кризовий фінансовий стан, коли запаси і витрати не покриваються всіма видами можливих джерел їх забезпечення (власних, позикових та ін.), підприємство перебуває на межі банкрутства.

Другим рівнем проведення аналізу фінансової стійкості сільськогосподарського підприємства $є$ аналіз його відносних показників.

Порівняння підходів різних науковців до оцінки фінансової стійкості підприємства дозволяє стверджувати, що найбільш поширеними є коефіцієнт автономії, коефіцієнт співвідношення власних і залучених коштів, коефіцієнт довгострокового залучення позикових коштів, коефіцієнт маневреності власних оборотних засобів і коефіцієнт реальної ціни.

Фінансовий стан підприємства характеризується різними факторами, які об'єднуються у певні групи. Ми виділили найголовніші показники та складові цих груп на рисунку 1.1.
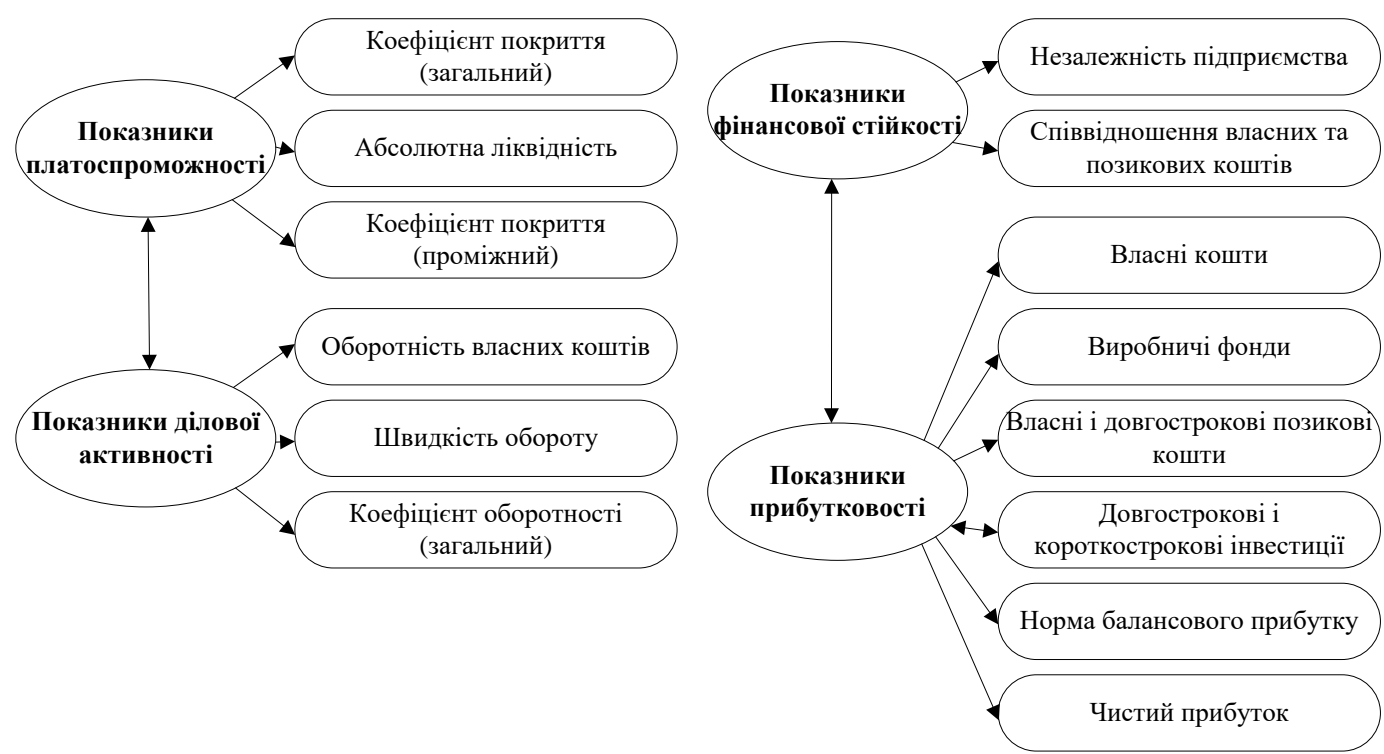

Рис. 1.1 Характерні показники аналізу фінансового стану підприємства 
Головною метою регулювання фінансового стану підприємства є своєчасне виявлення проблеми та ії знешкодження, розробка та реалізація плану щодо оперативного відновлення платоспроможності, утримання фінансової стійкості, розробка програм на майбутнє з теми розвитку підприємства, а також виявлення та закріплення можливості продовжувати підприємством свою господарську, економічну, фінансову діяльність, яка забезпечить йому зростання виробництва, стійкість під час кризових явищ, платоспроможність, ліквідність та прибутковість.

Регулювання фінансової стійкості в системі фінансово-економічної безепеки можливо досягнути лише за поєднання доцільно спрямованого взаємовпливу всіх iï складових елементів. Для цього він повинен відповідати таким вимогам: спрямовання дії всіх елементів фінансового механізму, який забезпечує інтереси всіх суб'єктів фінансових відносин; своєчасність реакції елементів фінансового механізму вищого рівня на зміни, які відбуваються під впливом елементів нижчого рівня див. рис.1.2.

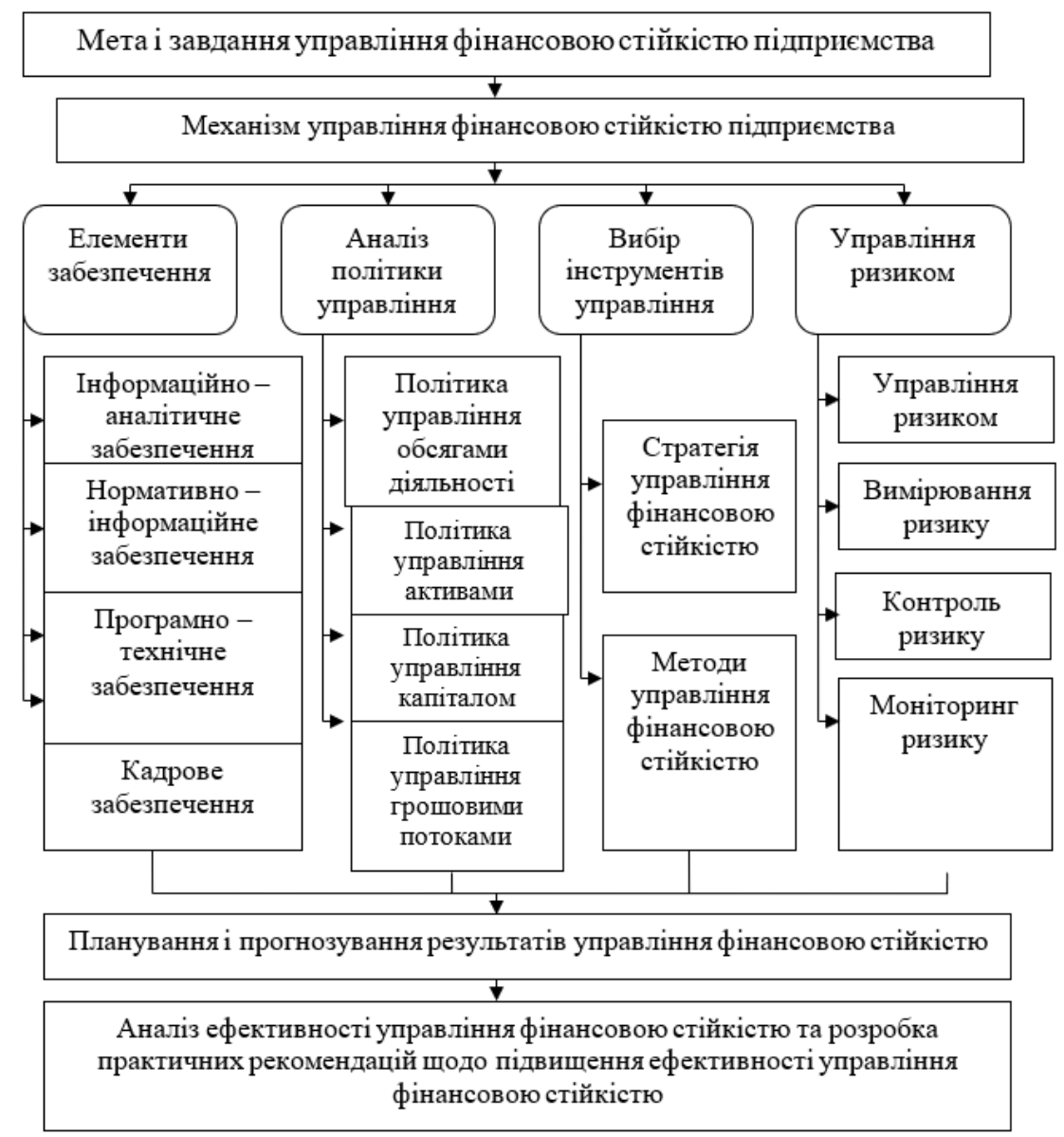

Рис.1.2 Основні складові управління та регулювання фінансової стійкості підприємства 
Розглянемо детально сутність кожного з механізмів, які застосовуються на окремих етапах фінансової стабілізації даного підприємства.

1. Оперативний механізм регулювання фінансової стійкості є системою заходів, що направлена, з одного боку, на зменшення поточних зовнішніх i внутрішніх фінансових зобов'язань підприємства, а з іншого, - на збільшення грошових активів, що забезпечують ці зобов'язання.

2. Тактичний механізм регулювання фінансової стабілізації полягає у збільшенні обсягу додатного грошового потоку в майбутньому періоді та зниженні обсягу використання додаткових ресурсів у майбутньому періоді

3. Стратегічний механізм регулювання фінансової стабілізації є системою заходів, що заснована на використанні моделей фінансової підтримки прискореного економічного зростання підприємства. Ця система заходів визначає необхідність перегляду окремих напрямів фінансової стратегії.

Отже, для ефективної оцінки, регулювання та управління фінансовою стійкістю підприємства, необхідно проводити систематичний фінансовий аналіз основних техніко-економічних та фінансових показників його діяльності та розробляти шляхи вдосконалення в нестабільних умовах господарювання.

На сьогодні наявний кризовий стан економіки України, дефіцит державного бюджету, зниження рівня ефективності виробництва спонукають вітчизняних підприємців до постійного пошуку нових шляхів забезпечення ефективності ведення бізнесу. В цій ситуації постає необхідність застосовувати світовий досвід покращення фінансово-економічного стану підприємств.

Світовий досвід переконливо доводить, що успіх підприємства залежить від здатності адаптуватись до змін в умовах посилення конкуренції на ринку 3 метою запобігання ризику зниження фінансової ефективності діяльності підприємства. Уряд зарубіжних держав має цілий ряд методів впливу на розв’язання проблемних питань в частині визначення оптимальних шляхів покращення фінансового стану підприємств.

Проведений аналіз наукових публікацій засвідчив, що фінансовий стан - це складна, інтегрована за багатьма показниками характеристика діяльності 
підприємства в певному періоді, що відображає ступінь забезпеченості підприємства фінансовими ресурсами, раціональності їх розміщення, забезпеченості власними оборотними коштами для своєчасного проведення грошових розрахунків за своїми зобов'язаннями та здійснення ефективної господарської діяльності в майбутньому.

Аналіз фінансового стану підприємства передбачає проведення аналізу його діяльності за певними напрямками. Ці напрями мають певні відмінності як у вітчизняній практиці та зарубіжному досвіді, рис. 1.3.

\begin{tabular}{|c|c|}
\hline \multicolumn{2}{|c|}{ Напрямки проведення фінансового аналізу підприємства } \\
\hline$\downarrow$ & $\nabla$ \\
\hline Український досвід & Зарубіжний досвід \\
\hline$\nabla$ & $\downarrow$ \\
\hline $\begin{array}{l}\text { - оцінка майнового стану; } \\
\text { - аналіз ділової активності; } \\
\text { - аналіз рентабельності; } \\
\text { - аналіз ліквідності та } \\
\text { платоспроможності; } \\
\text { - аналіз фінансової стійкості; } \\
\text { - аналіз фінансових } \\
\text { результатів діяльності } \\
\text { підприємства. }\end{array}$ & $\begin{array}{l}\text { - аналіз активів } \\
\text { (assets management rations); } \\
\text { - аналіз пасивів (зобов’язань, } \\
\text { довгострокової платоспроможності, } \\
\text { фінансового важеля) } \\
\text { (debts management rations, long- } \\
\text { termsolvency, financial leverage); } \\
\text { - аналіз ліквідності та } \\
\text { платоспроможності (liquidity and short- } \\
\text { term solvency); } \\
\text { - аналіз прибутковості (profitability); } \\
\text { - аналіз ринкової вартості (market value). }\end{array}$ \\
\hline
\end{tabular}

Рис. 1.3 Відмінності у напрямах проведення фінансового аналізу

В науково-дослідницькій практиці українських та зарубіжних вчених досить широко застосовується горизонтальний, вертикальний, факторний, порівняльний та коефіцієнтний аналіз. При цьому аналіз проводиться як за абсолютними, так і за відносними показниками.

У зарубіжній практиці аналіз фінансового стану проводиться здебільшого шляхом коефіцієнтного аналізу (ratio analysis) за окремими напрямками аналізу. Кожен з авторів визначає склад використовуваних їм показників інтуїтивно, без серйозних обгрунтувань. Так, Р. Стівен для аналізу фінансової стійкості 
рекомендує використовувати 9 коефіцієнтів, Томас Р. Ітільсон - 10 , Роберт С. Хіггінс - 7 , Річ Гильдерслив - 8 . Всього ж у всіх розглянутих джерелах згадується близько сотні показників (приблизно на таку ж їх кількість орієнтовані і нові програмні продукти з фінансового аналізу) при відсутності обгрунтувань вибору коефіцієнтів.

Це дозволяє аналізувати різні підприємства не зважаючи на масштаби їх діяльності, визначаючи ефективність та прибутковість їх діяльності. Перевага віддається проведенню порівняльного аналізу (дані підприємства порівнюється 3 встановленими нормативами або показниками підприємств-конкурентів), трендового аналізу (trend analysis), який включає у себе вертикальний аналіз (common-size analysis), горизонтальний аналіз відносних показників (percent change analysis). Широко застосовується також факторний аналіз, особливо за допомогою моделі Дю Понту [390, с. 74].

Проведемо порівняння методик розрахунку показників фінансового стану підприємства за окремим напрямками та методиками, які використовують вітчизняні та зарубіжні науковці.

Згідно 3 наведеними методиками оцінка активів підприємства за допомогою зарубіжних та вітчизняних методів досить відрізняється. У зарубіжному досвіді у якості характеристики майнового стану підприємства виступають показники оборотності, що визначають ефективність використання вкладеного капіталу у виробничий процес. У вітчизняному досвіді крім визначеного підходу існує також оцінка майнового стану, яка включає у себе розрахунок показників придатності основних фондів підприємства, завантаженість оборотних активів та визначає загальну забезпеченість підприємства активами для здійснення виробничої діяльності.

Аналіз відносних величин, що характеризують фінансову стійкість підприємства збігається з аналізом пасивів у зарубіжній практиці. Крім спільних показників, що характеризують залежність підприємства від зовнішнього фінансування використовуються також показники покриття відсотків за запозиченнями тобто процес обслуговування боргу. 
У зарубіжному досвіді одним з основних напрямів аналізу фінансового стану підприємства $є$ аналіз його ринкової вартості. Досить часто реальна вартість фірми значно менша за iï ринкову вартість, тобто розвинутий фондовий ринок зарубіжних країн створює можливість підвищення вартості компанії за рахунок гудвіла, тоді як в українських підприємств така можливість відсутня.

Аналіз ринкової вартості проводиться за допомогою розрахунку та аналізу наступних показників. Доходність акцій (Price-earnings ratio), що визначає яка частина від чистого прибутку надходить на одну випущену акцію та визначається діленням чистого прибутку на кількість випущених акцій. Коефіцієнт «ціна/грошовий потік» (price/cash flow) визначає доходність акції за грошовим потоком, що проходить через підприємство під час його діяльності на одну акцію. Коефіцієнт ринкової ціни (market-to-book value) характеризує у якій мірі ринкова ціна акції перевищує ï балансову вартість та визначається відповідним співвідношенням.

Таким чином, спостерігається певна відмінність у переліку показників фінансового стану підприємства та методів розрахунку подібних показників. Крім того, вихідні дані (фінансова звітність) для розрахунку даних показників будуть відрізнятися від вітчизняної фінансової звітності, що спричинено відмінностями у проведенні обліку операцій в процесі виробничої діяльності підприємства [375, с. 65].

До переваг зарубіжних методик можна віднести їх конкретність та визначеність у кількісному складі показників та інтерпретації їх результатів, спрощеність таких методик аналізу та оцінки фінансового стану підприємств.

Українські методики аналізу фінансового стану навпаки характеризуються значною відмінністю серед різних авторів у наборі показників для аналізу того чи іншого напряму та різноманітною їх комбінацією. Таким чином, вітчизняна методика потребує уніфікації, зменшення кількості показників, що аналізуються. При цьому необхідно віддавати перевагу розрахунку тих показників, які мають найбільшу змістовність та необхідність для аналітика. 
У високорозвинених зарубіжних державах власники підприємств застосовують на практиці систему участі не тільки з причин ефекту їх потужної стимулюючої дії, а й через підтримку з боку держави, яка забезпечується звільненням від оподаткування сум участі у прибутках. Так держава стимулює підприємців до поширення даної системи. В одних країнах система участі застосовується власниками добровільно або під тиском профспілок, в інших обов'язково, у відповідності до чинного законодавства [390,с. 125]. Зокрема, у Франції система участі набула законодавчої чинності з 1967 року, і є обов'язковою для всіх приватних підприємств 3 кількістю працюючих більше 100 осіб [391, с. 190].

В США, у відповідності із чинним законодавством, підприємства, що застосовують у себе програму участі в прибутках, мають значні податкові пільги. При цьому витрати державного бюджету (пов'язані 3 даними пільгами) перекриваються податковими надходженнями від підприємств, що працюють ефективніше від впровадження таких програм. Зокрема, на початку 90-х років XX ст. система участі в прибутках охоплювала 22\% усіх працюючих американців. Дана система була поширена більше, ніж у 15\% компаній. Найчастіше вона функціонує у вигляді «відстрочених виплат», які стають джерелом пенсійних фондів [393].

Система участі в прибутках в Україні повинна мати свою специфіку використання. Зокрема, вона забезпечує високий економічний і соціальний ефект лише в тих випадках, коли працівники мають в своєму розпорядженні своєчасну і точну інформацію про результати діяльності підприємства. Тобто, задля стимулювання високоефективної діяльності працівників менеджерам необхідно доводити, що системи участі в прибутках діють тільки при реально одержуваному прибутку.

У зарубіжному досвіді в якості характеристики майнового стану підприємства виступають показники оборотності, що визначають ефективність використання вкладеного капіталу у виробничий процес див. таблицю 1.2. 
Таблиця 1.2

Аналіз оборотності активів (assets management)

\begin{tabular}{|c|c|c|}
\hline Назва показника & Формула для розрахунку & Характеристика \\
\hline $\begin{array}{c}\text { Коефіцієнт оборотності } \\
\text { необоротних активів }\end{array}$ & $\begin{array}{c}\text { Виручка від реалізації } \\
\text { продукціі/ вартість } \\
\text { основного капіталу }\end{array}$ & $\begin{array}{c}\text { Характеризуєефективність } \\
\text { використання необоротних } \\
\text { активів }\end{array}$ \\
\hline $\begin{array}{c}\text { Коефіцієнт оборотності } \\
\text { дебіторської заборгованості }\end{array}$ & $\begin{array}{c}\text { Дебіторська заборгованість / } \\
\text { Річний обсяг продажів }\end{array}$ & $\begin{array}{c}\text { Характеризуєефективність } \\
\text { кредитної політики } \\
\text { підприємства, швидкість } \\
\text { оплати наданих послуг, } \\
\text { товарів }\end{array}$ \\
\hline $\begin{array}{c}\text { Коефіцієнт обороту } \\
\text { кредиторської } \\
\text { заборгованості }\end{array}$ & $\begin{array}{c}\text { Собівартість реалізованих } \\
\text { товарів / Кредиторська } \\
\text { заборгованість }\end{array}$ & $\begin{array}{c}\text { Характеризує швидкість } \\
\text { обороту заборгованості } \\
\text { підприємства }\end{array}$ \\
\hline $\begin{array}{c}\text { Коефіцієнт оборотності } \\
\text { основних засобів }\end{array}$ & $\begin{array}{c}\text { Виручка від реалізації } \\
\text { продукції / Середньорічна } \\
\text { вартість основних засобів }\end{array}$ & $\begin{array}{c}\text { Характеризує швидкість } \\
\text { обороту основних засобів }\end{array}$ \\
\hline Коефіцієнт оборотності \\
оборотних коштів & Виручка від реалізації \\
& продукції / Поточні активи - \\
Поточні пасиви & $\begin{array}{c}\text { Відображає швидкість } \\
\text { обороту матеріальних і } \\
\text { грошових ресурсів } \\
\text { підприємства за світний } \\
\text { період }\end{array}$ \\
\hline
\end{tabular}

Аналіз рентабельності продукції зарубіжних підприємств проводиться за наступними показниками в таблиці 1.3.

Таблиця 1.3

Аналіз рентабельності (profitability)

\begin{tabular}{|c|c|c|}
\hline Назва показника & Формула для розрахунку & Характеристика \\
\hline $\begin{array}{c}\text { Рентабельність власного } \\
\text { капіталу (Return on equity } \\
\text { (ROE)) }\end{array}$ & $\begin{array}{c}\text { Чистий прибуток / Середня } \\
\text { частка власного капіталу }\end{array}$ & $\begin{array}{c}\text { Характеризує прибутковість } \\
\text { власного капіталу }\end{array}$ \\
\hline $\begin{array}{c}\text { Рентабельність активів } \\
\text { (Return on assets (ROA)) }\end{array}$ & $\begin{array}{c}\text { Чистий прибуток / Загальна } \\
\text { сума активів }\end{array}$ & $\begin{array}{c}\text { Показує загальну } \\
\text { прибутковість використання } \\
\text { майна підприємства }\end{array}$ \\
\hline $\begin{array}{c}\text { Рентабельність продажів } \\
\text { (Gross profit margin) }\end{array}$ & $\begin{array}{c}\text { Валовий прибуток / Виручка } \\
\text { від реалізації }\end{array}$ & $\begin{array}{c}\text { Показує, скільки прибутку } \\
\text { припадає на одиницю } \\
\text { реалізованої продукції }\end{array}$ \\
\hline
\end{tabular}


Методика проведення аналізу ліквідності і платоспроможності, яка застосовується на закордонних підприємствах наведена в таблиці 1.4.

Таблиця 1.4.

Аналіз ліквідності та платоспрожожності (liquidity and solvency)

\begin{tabular}{|c|c|c|}
\hline Назва показника & $\begin{array}{c}\text { Формула для } \\
\text { розрахунку }\end{array}$ & Характеристика \\
\hline $\begin{array}{l}\text { Коефіцієнт поточної } \\
\text { ліквідності (current } \\
\text { liquidity) }\end{array}$ & $\begin{array}{l}\text { Поточні активи / } \\
\text { Поточні пасиви }\end{array}$ & $\begin{array}{c}\text { Характеризує здатність покривати } \\
\text { поточні зобовязання за рахунок } \\
\text { оборотних коштів }\end{array}$ \\
\hline $\begin{array}{c}\text { Коефіцієнт швидкої } \\
\text { ліквідності (quick } \\
\text { liquidity) }\end{array}$ & $\begin{array}{c}\text { Поточні активи - } \\
\text { середньорічна } \\
\text { вартість основних } \\
\text { засобів / Поточні } \\
\text { пасиви }\end{array}$ & $\begin{array}{c}\text { Характеризує здатність підприємства } \\
\text { покривати поточні зобовязання } \\
\text { найбільш ліквідною частиною } \\
\text { оборотних активів }\end{array}$ \\
\hline $\begin{array}{l}\text { Коефіцієнт абсолютної } \\
\text { ліквідності (cash ratio) }\end{array}$ & $\begin{array}{c}\text { Грошові кошти та їх } \\
\text { еквіваленти / Поточні } \\
\text { пасиви }\end{array}$ & $\begin{array}{c}\text { Характеризує здатність підприємства } \\
\text { покривати найбільш термінові } \\
\text { зобовязання за рахунок грошових } \\
\text { коштів, еквівалентів та } \\
\text { короткострокових фінансових } \\
\text { інвестицій }\end{array}$ \\
\hline $\begin{array}{c}\text { Коефіцієнт } \\
\text { маневриності капіталу } \\
\text { (net working capital to } \\
\text { total assets) }\end{array}$ & $\begin{array}{l}\text { Власні оборотні } \\
\text { кошти / Сукупні } \\
\text { активи }\end{array}$ & $\begin{array}{l}\text { Характеризує частку капіталу } \\
\text { вкладеного в оборотні активи }\end{array}$ \\
\hline
\end{tabular}

Отже, застосування світового та вітчизняного досвіду показує, що вдосконалення фінансового стану сільськогосподарського підприємства можливе шляхом підвищення результативності розміщення та використання ресурсів підприємства. При цьому забезпечується розвиток виробництва чи інших сфер діяльності на основі зростання прибутку й активів, при збереженні платоспроможності та кредитоспроможності. 3 розвитком економіки i фінансового аналізу повинна удосконалюватися і розвиватися його методична основа. Методика фінансового аналізу, загалом, володіючи досить універсальною структурою, має масу нюансів і тонкощів, які неможливо врахувати, створюючи які-небудь загальні документи. Однак, якщо державні 
відомства пропонують суспільству певну систему критеріїв і нормативів, то вони повинні бути ретельно вивірені, обгрунтовані і несуперечливі.

Обов’язковим i основним складником покращення фінансового стану підприємства $є$ визначення рівня його фінансової безпеки, оскільки фінанси $є$ вимірником ефективності функціонування. У той же час фінансову безпеку підприємства потрібно розглядати як самостійний об’єкт дослідження через призму результатів діяльності підприємства. Свідченням цього є те, що фінансова безпека посідає особливе місце в системі економічної безпеки, об' єднуючи характеристики як економічної безпеки, так і фінансів підприємства, впливаючи абсолютно на всі сфери діяльності підприємства.

Звертаючись до наукових напрацювань з цієї теми, необхідно, перш за все, розглянути підходи науковців відносно їх розуміння сутності фінансової безпеки. Так, Грідчина М. вважає, що «фінансова безпека - це такий фінансовий стан, що характеризується, по-перше, збалансованістю та якістю сукупності фінансових інструментів, технологій та послуг, які використовуються підприємством, по-друге, стійкістю до зовнішніх та внутрішніх загроз, по-третє, здатністю фінансової системи підприємства забезпечити реалізацію його фінансових інтересів та задач достатніми обсягами фінансових ресурсів» [392, с. 34-38].

На думку Папехіна Р.С. «сутність фінансової безпеки підприємств полягає в здатності підприємства самостійно розробляти i проводити фінансову стратегію відповідно до цілей загальної корпоративної стратегії, в умовах невизначеного i конкурентного середовища». 3 точки зору Кузенко Т.Б., Прохорової В.В. „фінансова безпека може бути визначена як стан найбільш ефективного використання інформаційних, фінансових показників, ліквідності та платоспроможності, рентабельності капіталу, що знаходиться в межах своїх граничних значень" [393, с.27-30].

Можна погодитися 3 тим, що фінансова безпека представляє такий стан підприємства, який дозволяє забезпечити фінансову рівновагу, стійкість, платоспроможність і ліквідність підприємства в довгостроковому періоді; 
задовольняє потреби підприємства у фінансових ресурсах для стійкого розширеного відтворення підприємства; забезпечує достатню фінансову незалежність підприємства; дозволяє протистояти існуючим i виникаючим небезпекам і погрозам, що можуть заподіяти фінансовий збиток підприємству, або небажано змінити структуру капіталу, або примусово ліквідовувати підприємство; забезпечує достатню гнучкість при ухваленні фінансових рішень; забезпечує захищеність фінансових інтересів власників підприємства.

Під фінансовою безпекою підприємства розуміють такий фінансовий стан, що характеризується, по-перше, збалансованістю та якістю сукупності фінансових інструментів, технологій i послуг, які використовуються підприємством, по-друге, стійкістю до внутрішніх і зовнішніх загроз, по-третє, здатністю фінансової системи підприємства забезпечувати реалізацію його фінансових ресурсів, по-четверте, забезпечувати розвиток фінансової системи.

3 іншого боку, фінансова безпека підприємства може визначатися, як стан найбільш ефективного використання корпоративних ресурсів підприємства, що виражається у високих значеннях фінансових показників прибутковості й рентабельності бізнесу, структури його капіталу, норми дивідендних виплат за цінними паперами, а також курсової вартості його цінних паперів як синтетичного індикатора поточного фінансово-господарського стану підприємства і перспектив його розвитку. Проте це визначення не враховує здатності підприємства реалізовувати місію своєї діяльності та задовольняти свої фінансові інтереси.

Найбільш повне визначення фінансової безпеки наводить І. Бланк: фінансова безпека підприємства являє собою кількісно та якісно визначений рівень його фінансового стану, що забезпечує стабільну захищеність його пріоритетних збалансованих фінансових інтересів від ідентифікованих реальних і потенційних загроз зовнішнього та внутрішнього характеру, параметри якого визначаються на основі його фінансової філософії і створюють необхідні умови для фінансової підтримки його стійкого зростання в поточному і перспективному періодах. 
Відтак, фінансова безпека підприємства $є$ динамічною ознакою фінансового стану підприємства, яка відображає його стійкість до внутрішніх і зовнішніх загроз, здатність до сталого й збалансованого розвитку та захисту своїх фінансових інтересів.

Необхідно зауважити, що у науковій літературі виділяють три рівні фінансової безпеки - держави, підприємства та особи. Зона спільних інтересів усіх вказаних суб'єктів обмежується сталим економіко-правовим середовищем. Проте існує суперечність між інтересами різних рівнів економічної безпеки загалом та фінансової зокрема. Так, на рівні підприємства основним інтересом $\epsilon$ відтворення процесу виробництва, на рівні держави - перерозподіл ресурсів, а на рівні особи - споживання благ.

Враховуючи наведені вище визначення фінансової безпеки, можна виділити такі умови забезпечення фінансової стабільності підприємства:

- високий ступінь гармонізації, узгодження фінансових інтересів підприємства 3 інтересами навколишнього середовища;

- наявність на підприємстві стійкої до загроз фінансової системи, яка спроможна забезпечувати реалізацію фінансових інтересів, місії та завдань;

- збалансованість і комплексність фінансових інструментів, що використовуються на підприємстві;

- постійний розвиток фінансової системи підприємства.

Широке й неоднозначне розуміння сутності фінансової безпеки створює труднощі щодо оцінки іiі рівня, і тому спеціальна література поки що не визначилася із методичним забезпеченням діагностики фінансової безпеки.

Дослідження та аналіз розроблених методологій оцінки рівня фінансової безпеки показав, що їх можна умовно поділити на дві основні групи: традиційні та нетрадиційні. Нетрадиційні методи засновані на оцінці та аналізу ризиків й визначенні ринкової вартості підприємства, проте в сучасній вітчизняній літературі дані методи не набули значного поширення. Основними їх недоліками $€$ складність під час аналізу та необхідність значної кількості важкодоступної інформації стосовно ринкових тенденцій. Серед українських науковців більше 
поширені традиційні методи, які засновані на оцінці надійності та стабільності функціонування підприємства. У таблиці 1.5. представлено найбільш розповсюджені методи оцінки.

Таблиця 1.5

Методичні підходи до оцінки фінансової безпеки підприємства

\begin{tabular}{|c|c|}
\hline Автори & Характеристика методу \\
\hline $\begin{array}{l}\text { Портнова Г.О., } \\
\text { Антоненко В.М. }\end{array}$ & $\begin{array}{l}\text { Інтегральний метод оцінки на основі визначення балів за кожним із } \\
\text { п'яти показників, що характеризують фінансову стійкість, ліквідність } \\
\text { та рентабельність активів. }\end{array}$ \\
\hline $\begin{array}{l}\text { Рета М.В., } \\
\text { Іванова А.О. }\end{array}$ & $\begin{array}{l}\text { Інтегральний метод оцінки, заснований на визначенні шести } \\
\text { показників, що характеризують фінансову стійкість та } \\
\text { платоспроможність підприємства. Інтегральне значення пропонується } \\
\text { вимірювати відносно нормального та критичного значень. }\end{array}$ \\
\hline $\begin{array}{l}\text { Рзаєва Т.Г., } \\
\text { Бондар Г.А. }\end{array}$ & $\begin{array}{l}\text { Інтегральний метод на основі } 11 \text { показників, що характеризують } \\
\text { фінансову стійкість, ділову активність, ринкову вартість та } \\
\text { інвестиційну привабливість. Пропонується визначення інтегрального } \\
\text { показника, проте відсутня інтерпретація результатів. }\end{array}$ \\
\hline Горячева К.С. & $\begin{array}{l}\text { Ресурсно-функціональний, інтегральний підхід. Пропонується } \\
\text { визначення інтегрального показника на основі визначення безпеки за } \\
\text { кожним функціональним складником: бюджетним, грошов-- } \\
\text { кредитним, валютним, банківським, інвестиційним, фондовим, } \\
\text { страховим. }\end{array}$ \\
\hline Литовченко О.Ю. & $\begin{array}{l}\text { Інтегральний метод на основі бальної оцінки п’яти показників, що } \\
\text { характеризують фінансову стійкість, ділову активність та ліквідність. } \\
\text { Ресурсно-функціональний підхід, що базується на основі визначення } \\
\text { інтегрального показника за кожним функціональним складником. У } \\
\text { моделі відсутні вагові значення та інтерпретація результатів. }\end{array}$ \\
\hline Почечун O.I. & $\begin{array}{l}\text { Індикаторний підхід. Оцінка фінансової безпеки на основі визначення } \\
12 \text { показників, що характеризують платоспроможність, ліквідність, } \\
\text { ділову активність, та порівняння розрахованих значень із } \\
\text { нормативними. }\end{array}$ \\
\hline Чернега О.М. & $\begin{array}{l}\text { Ресурсно-функціональний підхід. Визначення інтегрального показника } \\
\text { виходячи із часткових функціональних критеріїв безпеки. При цьому } \\
\text { перелік функціональних складників, показників та їх інтерпретація не } \\
\text { визначений. }\end{array}$ \\
\hline
\end{tabular}

Як стало зрозуміло з аналізу сучасних підходів до оцінки рівня фінансової безпеки підприємства, таку оцінку рівня пропонується здійснювати по кожній функціональній складовій фінансової безпеки, а потім експертним шляхом визначати інтегральний показник.

До функціональної структури фінансової діяльності і відповідно фінансової безпеки підприємства відносяться такі: 
- бюджетна - взаємовідносини з бюджетом (податки і збори до бюджетів, при наявності - бюджетні кредити або бюджетне фінансування);

- грошово-кредитна - кредити під операційну діяльність, виплата заробітної плати працівникам, розрахунки 3 постачальниками і отримання грошових коштів від покупців продукції і послуг;

- валютна - при здійсненні експортно-імпортних операцій (купівля і продаж валюти, кредити в іноземних валютах, розрахунки 3 іноземними споживачами і постачальниками продукції та послуг у валюті);

- банківська - взаємовідносини підприємства з банками по кредитах i депозитах;

- інвестиційна - капітальні вкладення у розвиток підприємства, у тому числі - за рахунок довгострокових кредитів;

- фондова - випуск підприємством власних акцій і купівля акцій інших підприємств,

- страхова - страхування майна підприємства або результатів його діяльності, безпечної праці ізбереження здоров’я працівників.

Оцінка фінансової безпеки підприємства передбачає, перш за все, ідентифікацію його фінансового стану. Проведені дослідження дозволили зробити певні кроки в напрямку формування системи показників для оцінки фінансової безпеки. Вибір кожного окремого показника аргументований у таблиці 1.6., де визначені його характеристика та вплив на загальний стан фінансової безпеки підприємства.

Відзначимо, що найбільший вплив на фінансову безпеку справляють показники фінансової стабільності підприємства, оскільки відображають залежність підприємства від зовнішніх чинників, а отже, характеризують захищеність підприємства від зовнішніх загроз, пов'язаних, головним чином, iз нестабільністю банківського сектора та можливістю неплатоспроможності підприємств-партнерів.

Кожному із показників за допомогою експертного методу було надано свій ранг залежно від впливу показників на фінансову безпеку промислового 
підприємства, при цьому найменше значення рангу означає найбільший вплив, а найбільше - найменший. Зауважимо, що ранг повинен переглядатися залежно від стану ринкової кон’юнктури, ситуації як на фінансовому ринку, так і в реальному секторі, а також ураховувати специфіку діяльності галузі або самого підприємства, його стратегію та цілі.

Таблиця 1.6.

Вагові значення системи показників моделі оцінювання рівня фінансової безпеки підприємства

\begin{tabular}{|c|c|c|c|c|}
\hline № & Показник & Характеристика та вплив на фінансову безпеку & Ранг & $\begin{array}{c}\text { Вагове } \\
\text { значення }\end{array}$ \\
\hline 1 & Фондовіддача & $\begin{array}{l}\text { Показник відображає суму реалізованої валової } \\
\text { продукції, що припадає на } 1 \text { грн. основних засобів та } \\
\text { фактично характеризує ефективність використання } \\
\text { основних засобів. Низький рівень даного показника } \\
\text { та його зменшення стверджують про неефективність } \\
\text { використання основних засобів, а отже, наявність } \\
\text { ризику неефективності операційної діяльності та } \\
\text { майбутнього недоотримання прибутку }\end{array}$ & 13 & 0,03 \\
\hline 2 & $\begin{array}{l}\text { Коефіцієнт } \\
\text { придатності } \\
\text { основних засобів }\end{array}$ & $\begin{array}{l}\text { Коефіцієнт відображає технічний стан наявних } \\
\text { основних фондів. Низьке значення коефіцієнта та } \\
\text { його зменшення свідчать про необхідність оновлення } \\
\text { основних засобів, що призводить до додаткових } \\
\text { фінансових втрат у майбутніх періодах }\end{array}$ & 15 & 0,01 \\
\hline 3 & $\begin{array}{l}\text { Коефіцієнт } \\
\text { покриття }\end{array}$ & $\begin{array}{l}\text { Коефіцієнт характеризує достатність } \\
\text { ресурсів підприємства для погашення пох поточних } \\
\text { зобов'язань та та відображає } \\
\text { неплатоспроможності, одного з основних ризиків } \\
\text { фінансової безпеки підприємства. Низький рівень } \\
\text { коефіцієнту означає нездатність підприємства } \\
\text { відповідати за своїми боргами та є ознакою його } \\
\text { неплатоспроможності }\end{array}$ & 6 & 0,08 \\
\hline 4 & $\begin{array}{l}\text { Коефіцієнт } \\
\text { швидкої } \\
\text { ліквідності }\end{array}$ & $\begin{array}{l}\text { Коефіцієнт відображає можливість } \quad \text { погашення } \\
\text { поточних зобов'язань підприємства за рахунок наявних } \\
\text { грошових засобів та дебіторської заборгованості, яка не } \\
\epsilon \quad \text { простроченою. Фактично характеризує } \\
\text { платоспроможність підприємства за умови своєчасних } \\
\text { розрахунків із дебіторами. }\end{array}$ & 5 & 0,08 \\
\hline 5 & $\begin{array}{l}\text { Коефіцієнт } \\
\text { абсолютної } \\
\text { ліквідності }\end{array}$ & $\begin{array}{l}\text { Коефіцієнт характеризує здатність підприємства } \\
\text { відповідати за своїми поточними зобов’язаннями за } \\
\text { рахунок найбільш ліквідних коштів. Низький рівень } \\
\text { коефіцієнту стверджує про неможливість сплати } \\
\text { підприємством поточних зобов'язань без залучення } \\
\text { коштів дебіторів. Своєю чергою, особливо за } \\
\text { несприятливої кон'юнктури є ризик неповернення } \\
\text { коштів дебіторів, що підриває платоспроможність } \\
\text { підприємства та загрожує його фінансовій безпеці. }\end{array}$ & 4 & 0,09 \\
\hline
\end{tabular}


Продовження таблиці 1.6.

\begin{tabular}{|c|c|c|c|c|}
\hline 6 & $\begin{array}{l}\text { Коефіцієнт } \\
\text { автономії }\end{array}$ & $\begin{array}{l}\text { Коефіцієнт показує питому вагу власного капіталу, } \\
\text { найбільш надійного джерела фінансування, у загальній } \\
\text { сумі джерел фінансування. Чим вище даний показник, } \\
\text { тим менший ризик фінансової залежності підприємства } \\
\text { від зовнішніх джерел фінансування та вищий рівень } \\
\text { фінансової безпеки. Проте занизький рівень власного } \\
\text { капіталу стримує економічний розвиток підприємства. }\end{array}$ & 2 & 0,1 \\
\hline 7 & $\begin{array}{l}\text { Коефіцієнт } \\
\text { фінансової } \\
\text { стійкості }\end{array}$ & $\begin{array}{l}\text { Коефіцієнт відображає співвідношення між власним } \\
\text { та залученим капіталом та показує, скільки гривень } \\
\text { власного капіталу припадає на одиницю залученого. } \\
\text { Низьке значення коефіцієнту стверджує про } \\
\text { незадовільну структуру джерел фінансування } \\
\text { підприємства та наявність реальної загрози } \\
\text { фінансовій безпеці підприємства. }\end{array}$ & 1 & 0,11 \\
\hline 8 & $\begin{array}{l}\text { Коефіцієнт } \\
\text { довгострокової } \\
\text { фінансової } \\
\text { незалежності }\end{array}$ & 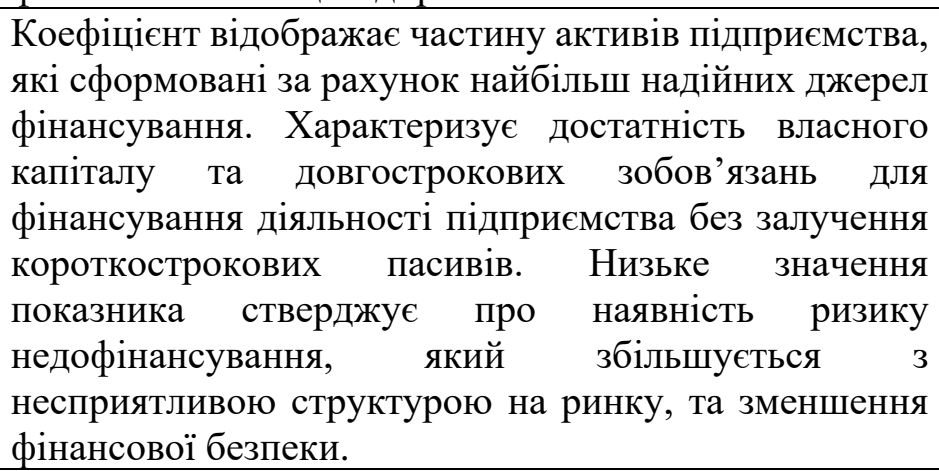 & 3 & 0,1 \\
\hline 9 & $\begin{array}{l}\text { Коефіцієнт } \\
\text { маневреності } \\
\text { власного } \\
\text { капіталу }\end{array}$ & $\begin{array}{l}\text { Коефіцієнт відображає частину власного капіталу, що } \\
\text { спрямовується для фінансування поточної діяльності. } \\
\text { Характеризує достатність власних джерел для } \\
\text { фінансування поточної діяльності. Низьке значення } \\
\text { коефіцієнту стверджує про необхідність залучення } \\
\text { додаткових джерел для фінансування діяльності } \\
\text { підприємства, а отже, і зниження рівня безпеки. }\end{array}$ & 8 & 0,07 \\
\hline 10 & $\begin{array}{l}\text { Співвідно- } \\
\text { шення } \\
\text { оборотності } \\
\text { дебіторської і } \\
\text { кредиторської } \\
\text { заборгованості }\end{array}$ & 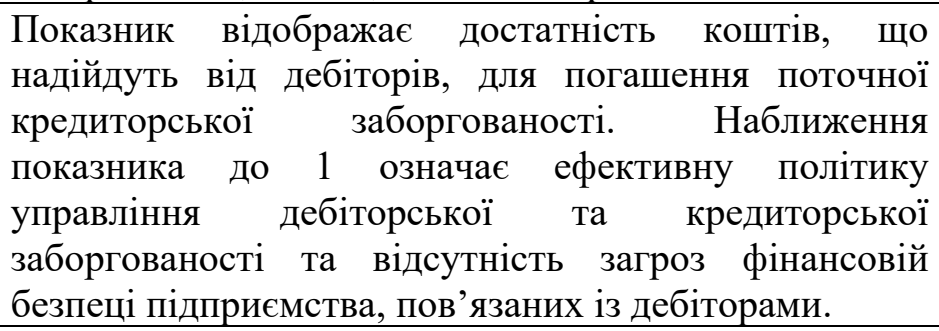 & 7 & 0,07 \\
\hline 11 & $\begin{array}{l}\text { Коефіцієнт } \\
\text { зміни } \\
\text { оборотності } \\
\text { оборотних } \\
\text { коштів } \\
\end{array}$ & $\begin{array}{l}\text { Коефіцієнт показує у скільки разів збільшився } \\
\text { коефіцієнт оборотності оборотних активів за звітний } \\
\text { період та відображає ефективність їх використання. } \\
\text { Тенденція до зростання свідчить про зростання } \\
\text { ефективності управління оборотними коштами. }\end{array}$ & 14 & 0,02 \\
\hline 12 & $\begin{array}{l}\text { Коефіцієнт } \\
\text { зміни валюти } \\
\text { балансу }\end{array}$ & $\begin{array}{l}\text { Коефіцієнт показує у скільки разів зросла сума } \\
\text { активів підприємства за звітний період. Характеризує } \\
\text { загальну динаміку підприємства. Низьке значення } \\
\text { показника стверджує про негативні явища на } \\
\text { підприємстві та скорочення виробничої діяльності, а } \\
\text { високі - про розширення виробництва та можливість } \\
\text { зростання прибутків у майбутніх періодах. }\end{array}$ & 16 & 0,01 \\
\hline
\end{tabular}


Продовження таблиці 1.6.

\begin{tabular}{|c|c|c|c|c|}
\hline 13 & $\begin{array}{l}\text { Коефіцієнт } \\
\text { зміни чистого } \\
\text { прибутку }\end{array}$ & $\begin{array}{l}\text { Коефіцієнт показує у скільки разів зросла сума } \\
\text { чистого прибутку підприємства за звітний період. } \\
\text { Характеризує загальну прибутковість підприємства. } \\
\text { Низьке значення показника стверджує про зменшення } \\
\text { ефективності діяльності підприємства }\end{array}$ & 9 & 0,06 \\
\hline 14 & $\begin{array}{l}\text { Рентабельність } \\
\text { власного } \\
\text { капіталу }\end{array}$ & $\begin{array}{l}\text { Коефіцієнт відображає віддачу власного капіталу та } \\
\text { показує величину прибутку в розрахунку на } 1 \text { грн. } \\
\text { вкладеного власниками капіталу. Характеризує } \\
\text { ефективність вкладених коштів у підприємства. } \\
\text { Низьке значення показника означає неефективне } \\
\text { використання вкладених коштів. }\end{array}$ & 12 & 0,03 \\
\hline 15 & $\begin{array}{l}\text { Рентабельність } \\
\text { активів }\end{array}$ & $\begin{array}{l}\text { Показник показує величину прибутку в розрахунку на } \\
1 \text { грн. активів та відображає ефективність } \\
\text { використання активів підприємства. Низьке значення } \\
\text { показника стверджує про неефективне управління } \\
\text { підприємством та наявність можливих загроз } \\
\text { фінансовій безпеці через неефективну діяльність } \\
\text { підприємства. }\end{array}$ & 11 & 0,04 \\
\hline 16 & $\begin{array}{l}\text { Рентабельність } \\
\text { продажу }\end{array}$ & $\begin{array}{l}\text { Коефіцієнт відображає величину чистого прибутку, що } \\
\text { приходиться на } 1 \text { грн. виручки від реалізації, а також дає } \\
\text { можливість оцінити частку собівартості у продажах. } \\
\text { Низьке значення означає неефективну діяльність } \\
\text { підприємства через високий рівень собівартості } \\
\text { наявність загроз фінансовій безпеці підприємства. }\end{array}$ & 10 & 0,05 \\
\hline
\end{tabular}

Для визначення вагового значення кожного показника було використано формулу Фішберна, яка дає змогу розрахувати їх виходячи із ранжування показників в таблиці 1.7.

Таблиця 1.7.

Оцінка рівня фінансової безпеки промислового підприємства

\begin{tabular}{|c|c|l|}
\hline $\begin{array}{c}\text { Рівень фінансової } \\
\text { безпеки }\end{array}$ & Значення IFS & \multicolumn{1}{|c|}{ Характеристика стану } \\
\hline Відмінний & $1,17<I F S$ & $\begin{array}{l}\text { Підприємство бездоганно протистоїть зовнішнім } \\
\text { та внутрішнім загрозам, що створює підгрунтя } \\
\text { для стабільного розвитку та реалізації стратегії } \\
\text { підприємства у майбутніх періодах }\end{array}$ \\
\hline Задовільний & $0,93<I F S<1,17$ & $\begin{array}{l}\text { Підприємство здатне протистояти зовнішнім та } \\
\text { внутрішнім загрозам, що забезпечує його } \\
\text { розвиток у майбутньому періоді }\end{array}$ \\
\hline Незадовільний & $0,56<I F S<0,93$ & $\begin{array}{l}\text { Підприємство не здатне протистояти зовнішнім } \\
\text { та внутрішнім загрозам, що загрожує } \\
\text { ефективному функціонуванню підприємства в } \\
\text { майбутніх періодах }\end{array}$ \\
\hline Критичний & IFS $<0,56$ & $\begin{array}{l}\text { Підприємство не протистоїть зовнішнім та } \\
\text { внутрішнім загрозам, тому є велика ймовірність } \\
\text { утрати платоспроможності й банкрутства }\end{array}$ \\
\hline
\end{tabular}


Відповідно до отриманих результатів аналізу визначається рівень фінансової безпеки суб’єкта господарювання:

- високий рівень фінансової безпеки (фінансові показники знаходяться в межах порогових значень та якісні показники за бальними значеннями відповідають встановленим вимогам);

- середній рівень фінансової безпеки (значення хоча б одного з фінансових показників не відповідає нормативним межам та не усі якісні показники відповідають вимогам);

- низький рівень фінансової безпеки (значення більшості фінансових показників не відповідають нормативам та спостерігаються загрози).

У світовій практиці вже накопичений достатній досвід оцінки рівня фінансово-економічної безпеки підприємств. Для цих цілей кожному первинному фінансовому показнику приписується деякий фінансовий коефіцієнт. Як мінімальний критерій стійкості фінансового стану підприємства, як правило, використовується імовірність банкрутства. До таких моделей можна віднести: модель Альтмана, модель Ліса, метод Депаляна, метод Таффлера, метод Спрингейта, модель Фулмера, показники діагностики платоспроможності Конона і Гольдера, модель Бівера, тощо.

На сьогодні українськими вченими вже розроблені такі моделі, як дискримінанта інтегральна оцінка фінансового стану підприємства (Терещенко О.М.), яка базується на застосуванні методології дискримінантного аналізу на основі фінансових показників вибіркової сукупності вітчизняних підприємств i комплексна оцінка фінансового стану підприємства на основі використання матричних моделей (О. Хотомлянський, Т. Перната, Г. Северина). Цей метод оцінки дозволяє виявити тенденції у динаміці фінансового стану підприємства.

Враховуючи досвід вітчизняних та зарубіжних економістів, слід зазначити, що інтегральна бальна оцінка фінансової стійкості найбільш повно охоплює всю різноманітність показників фінансової стійкості, що дуже важливо при оцінці ризику банкрутства. Сутність цієї методики полягає в класифікації підприємств 
за ступенем ризику, виходячи 3 фактичного рівня показників фінансової стійкості і рейтингу показника, вираженого в балах.

При цьому виділяється шість класів підприємств:

1-й клас - підприємство з добрим запасом фінансової стійкості, що дозволяє бути впевненим у поверненні позикових коштів;

2-й клас - підприємства, що демонструють деякий ступінь ризику по заборгованості, але ще не розглядаються як ризикові;

3-й клас - проблемні підприємства, для яких існує ризик втрати основних i оборотних засобів, але повне отримання процентів є сумнівним;

4-й клас - підприємства 3 високим ризиком банкрутства навіть після проведення заходів 3 фінансового оздоровлення, щодо яких кредитори ризикують втратити свої проценти і позиковий капітал;

5-й клас - підприємства дуже високого ризику, практично неплатоспроможні;

6-й клас - підприємства найвищого ризику.

Згідно з цією методикою, фінансовий стан підприємства оцінюється шістьма коефіцієнтами, в основі визначення яких лежить величина оборотних активів різного ступеня ліквідності. Групування підприємств за такими критеріями оцінки фінансового стану представлено у таблиці 1.8.

В залежності від величини того чи іншого коефіцієнта кожному класу підприємств присвоюється відповідний бал. В таблиці 1.8 наведена та мінімальна кількість балів, яка буде визначати клас небезпек підприємства.

Таблиця 1.8

Групування підприємств за критеріями оцінки фінансового стану

\begin{tabular}{|l|c|c|c|c|c|c|}
\hline \multirow{2}{*}{ Показник } & \multicolumn{5}{|c|}{ Границі класів згідно з критеріями (бал) } \\
\cline { 2 - 7 } & 1 -й клас & 2 -й клас & 3-й клас & 4 -й клас & 5-й клас & 6-й клас \\
\hline $\begin{array}{l}\text { Kоефіцієнт абсолютної } \\
\text { ліквідності }\end{array}$ & $\begin{array}{c}\text { більше } \\
0,25-20\end{array}$ & $0,2-16$ & $0,15-12$ & $0,1-8$ & $0,05-4$ & $0,05-0$ \\
\hline $\begin{array}{l}\text { Коефіцієнт швидкої } \\
\text { ліквідності }\end{array}$ & $\begin{array}{c}\text { більше } \\
1,0-18\end{array}$ & $0,9-15$ & $0,8-12$ & $0,7-9$ & $0,6-6$ & $0,5-0$ \\
\hline
\end{tabular}


Продовження таблиці 1.8

\begin{tabular}{|l|c|c|c|c|c|c|}
\hline $\begin{array}{l}\text { Коефіцієнт поточної } \\
\text { ліквідності }\end{array}$ & $\begin{array}{c}\text { більше } \\
2,0-16,5\end{array}$ & $1,9-15$ & $1,6-11$ & $1,3-6$ & $1,0-1,5$ & $\begin{array}{c}\text { менше } \\
1-0\end{array}$ \\
\hline $\begin{array}{l}\text { Коефіцієнт фінансової } \\
\text { незалежності }\end{array}$ & $\begin{array}{c}\text { більше } \\
0,6-16\end{array}$ & $0,5-15$ & $0,4-11$ & $0,35-7$ & $0,3-1$ & $\begin{array}{c}\text { менше } \\
0,4-0\end{array}$ \\
\hline $\begin{array}{l}\text { Коефіцієнт забезпеченості } \\
\text { власними оборотними } \\
\text { коштами }\end{array}$ & $\begin{array}{c}\text { більше } \\
0,5-15\end{array}$ & $0,4-12$ & $0,3-9$ & $0,2-6$ & $0,1-3$ & $\begin{array}{c}\text { менше } \\
0,1-0\end{array}$ \\
\hline $\begin{array}{l}\text { Коефіцієнт забезпе-ченості } \\
\text { запасів власним капіталом }\end{array}$ & $\begin{array}{c}\text { більше } \\
1,0-15\end{array}$ & $0,9-12$ & $0,8-9$ & $0,7-6$ & $0,6-3$ & менше \\
\hline $\begin{array}{l}\text { Мінімальне значення } \\
\text { границі, балів }\end{array}$ & 100 & $85-64$ & $64-57$ & $42-28$ & 18 & 0,0 \\
\hline
\end{tabular}

Інша методика визначення рівня фінансово-економічної безпеки залежно від стану оборотних активів полягає у зіставленні нормативних та фактичних значень індикаторів (таблиця 1.9).

Таким чином, у якості індикаторів рівня фінансової безпеки підприємства можуть виступати нормативні значення показників, розраховані на базі представлених методик. Визначити інтегральний показник рівня фінансової безпеки можна також методом рейтингової оцінки. В основі визначення класу (рівня) безпеки лежать граничні значення показників та їхній рейтинг. Якщо показник має значення вище нормального, то йому присвоюють I клас, нижче нормального, але вище критичного - присвоюють II клас, нижче критичного III клас. Так, для визначення класу рівня безпеки із приведених даних у табл. 1.9. відібрані п’ять.

Таблиця 1.9

Показники фінансового стану підприємства, для яких встановлено нормативні значення згідно з офіційними вітчизняними методиками

\begin{tabular}{|c|c|c|}
\hline Назва показника & Порядок розрахунку & Нормативне значення \\
\hline \multicolumn{2}{|c|}{ Методика Міністерства економіки України } \\
\hline $\begin{array}{c}\text { 1. Коефіцієнт поточної (загальної) } \\
\text { ліквідності }\end{array}$ & $\frac{\mathrm{OA}+\mathrm{BMП}}{\Pi 3}$ & $\geq 1,5$ \\
\hline 2. Коефіцієнт покриття & $\frac{\mathrm{OA}}{\Pi 3}$ & $>1$ \\
\hline
\end{tabular}


Продовження таблиці 1.9

\begin{tabular}{|c|c|c|}
\hline $\begin{array}{l}\text { 3. Коефіцієнт абсолютної ліквідності } \\
\text { (платоспроможності) }\end{array}$ & $\frac{\Gamma К+\Pi \Phi \mathrm{I}}{\Pi 3}$ & $0,1-0,2$ \\
\hline 4. Власні оборотні активи (ВОА) & $B K-H A$ & $>0$ \\
\hline $\begin{array}{c}\text { 5. Частка власних оборотних коштів у } \\
\text { покритті запасів, \% }\end{array}$ & $\frac{\mathrm{BOA} * 100}{3}$ & $>50 \%$ \\
\hline $\begin{array}{l}\text { 6. Коефіцієнт забезпечення власними } \\
\text { коштами }\end{array}$ & $\frac{\mathrm{BК}+3 \mathrm{HBП}+\text { ДМП - НА }}{\text { ОА }}$ & $\geq 0,1$ \\
\hline 7. Коефіцієнт фінансової автономії & $\frac{\mathrm{BK}}{\mathrm{5}}$ & $\geq 0,5$ \\
\hline \multicolumn{3}{|c|}{ Методика Міністерства фінансів України } \\
\hline 8. Коефіцієнт покриття & $\frac{\mathrm{OA}}{\Pi 3}$ & $>1$ \\
\hline 9. Коефіцієнт швидкої ліквідності & $\frac{\mathrm{OA}-3}{\Pi 3}$ & $0,6-0,8$ \\
\hline 10. Коефіцієнт абсолютної ліквідності & $\frac{\Gamma \mathrm{K}+\Pi \Phi \mathrm{I}}{\Pi 3}$ & $>0$ \\
\hline 11. Чистий оборотний капітал & $O A-\Pi 3$ & $>0$ \\
\hline $\begin{array}{l}\text { 12. Коефіцієнт платоспроможності } \\
\text { (автономії) }\end{array}$ & $\frac{\mathrm{BK}}{\mathrm{E}}$ & $>0,5$ \\
\hline 13. Коефіцієнт фінансування & 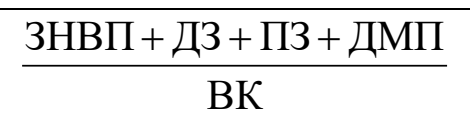 & $<1$ \\
\hline $\begin{array}{l}\text { 14. Коефіцієнт забезпеченості власними } \\
\text { оборотними коштами }\end{array}$ & $\frac{\mathrm{OA}-\Pi 3}{\mathrm{OA}}$ & $>0,1$ \\
\hline $\begin{array}{l}\text { 15. Коефіцієнт маневреності власного } \\
\text { капіталу }\end{array}$ & $\frac{\mathrm{OA}-\Pi 3}{\mathrm{BK}}$ & $>0$ \\
\hline
\end{tabular}

*Умовні позначення: Б - валюта балансу, НА - необоротні активи, ОА - оборотні активи, ВМП витрати майбутніх періодів, 3 - запаси, ГК - грошові кошти та їх еквіваленти, ПФІ - поточні фінансові інвестиції, ВК - власний капітал, ЗНВП - забезпечення наступних витрат і платежів, ДЗ довгострокові зобов’язання, ПЗ - поточні зобов’язання, ДМП - доходи майбутніх періодів.

Модель шкали, що включає відібрані показники, подана у таблиці 1.10. 
Таблиця 1.10

Шкала для оцінювання рівня фінансової безпеки підприємства

\begin{tabular}{|l|c|c|c|}
\hline \multicolumn{1}{|c|}{ Найменування показника } & I клас & II клас & III клас \\
\hline 1. Коефіцієнт автономії & більше 0,7 & $0,5-0,7$ & менше 0,5 \\
\hline 2. Коефіцієнт оборотності запасів & більше 1 & $0,5-1$ & менше 0,5 \\
\hline $\begin{array}{l}\text { 3. Коефіцієнт рентабельності активів за чистим } \\
\text { прибутком }\end{array}$ & більше 0,09 & $0,05-0,09$ & менше 0,05 \\
\hline 4. Коефіцієнт фінансового ризику & менше 0,5 & $0,5-1$ & більше 1 \\
\hline 5. Коефіцієнт абсолютної ліквідності & більше 0,4 & $0,4-0,2$ & менше 0,4 \\
\hline
\end{tabular}

Проведений аналіз впливу оцінки фінансового стану підприємства на рівень фінансово-економічної безпеки дозволяє зробити такі висновки:

- сутність існуючих методик оцінки фінансового стану полягає у виявленні рівня фінансової безпеки підприємства на базі розрахунку певних коефіцієнтів та співставленні їх значень із граничними (нормативними);

- використання для порівняння нормативних значень показників слід віднести до негативної сторони оцінювання рівня фінансового стану, оскільки, по-перше, вони для різних сфер економіки є неоднаковими, на галузевому рівні потребують постійного перерахунку, а по-друге, галузева специфіка діяльності підприємства вимагає для кожного 3 них диференційованого підходу до визначення нормативів ліквідності, рентабельності тощо;

- відсутнє урахування впливу факторів зовнішнього середовища на рівень фінансового стану підприємства, що 3 огляду на ієрархічність системи фінансової безпеки, є вкрай важливим;

- $\epsilon$ нагальна потреба у серйозній розробці та впровадженні інтегрованих рейтингових підходів до оцінки фінансового стану та його впливу на рівень фінансово-економічної безпеки підприємств, що нівелює недоліки існуючих підходів і підвищить їх адекватність ринковим умовам. 